\title{
Crack coalescence and strain accommodation in gypsum rock
}

\author{
Chiara Caselle \\ University of Torino, Department of Earth Science, Italy \\ chiara.caselle@unito.it, bttp://orcid.org/0000-0002-3081-1555 \\ Sabrina Bonetto \\ University of Torino, Department of Earth Science, Italy \\ sabrina.bonetto@unito.it, bttp://orcid.org/0000-0002-6579-1419

\section{Daniele Costanzo} \\ Polytechnic of Torino, Department of Structural, Geotechnical and Building Engineering, Italy \\ daniele.costanzo@polito.it, bttp://orcid.org/0000-0002-1957-275X
}

\begin{abstract}
The micro-mechanisms involved in the deformation of gypsum rock have for long time interested the scientific world and are still not completely understood.

The present work proposes an experimental investigation of strain accommodation in gypsum rock, reporting data referred to uniaxial and triaxial stress conditions. The rock deformation was investigated with a multiscale approach, with the comparison of results from DIC and microstructural analyses, aiming to propose an interpretation of crack coalescence and strain accommodation in natural gypsum rock (i.e. branching selenite facies), focusing on the influence of textural and compositional layering on the mechanical response.

The failure was observed to coalesce following an unstable step-wise process. With the increase of confining pressure, the material develops a structure of plastic accommodation of strain, favoured by the peculiar crystallographic structure of gypsum, with water molecules layered in the salt structure.
\end{abstract}

KEYwORDS. Gypsum; DIC analysis; Microstructure; Brittle-ductile transition.

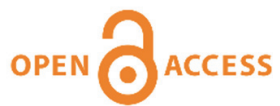

Citation: Caselle, C., Bonetto, S., Costanzo, D., Crack coalescence and strain accommodation in gypsum rock, Frattura ed Integrità Strutturale, 52 (2020) 247-255.

Received: 31.10 .2019

Accepted: 08.02.2020

Published: 01.04.2020

Copyright: (C) 2019 This is an open access article under the terms of the CC-BY 4.0, which permits unrestricted use, distribution, and reproduction in any medium, provided the original author and source are credited.

\section{INTRODUCTION}

ypsum is a soft rock that is involved in a wide range of industrial applications (e.g. it is a main component of
stucco, wallboards, cements, paints and soil conditioner/fertilizer; it is used in food industry as a flocculant and
in several clinical applications as regenerative material for bone defects, dental plaster, or as a delivery vehicle for
pharmaceutical agents [1]). Quarry sites, both open pit and underground, are therefore largely exploited all over the world. 
The stability assessment of quarry environments, both during the active exploitation or in abandoned conditions, requires an attentive investigation of mechanical response (e.g. [2-6]). The mechanical behaviour of gypsum rock also affects several frameworks of deep excavations, as inter-bed layer in evaporitic rock bodies (e.g.[7]) or as a caprock in oil reservoirs. The investigation of mechanical response of gypsum rock is complicated by the high heterogeneity in terms of porosity, grain size, mineralogical composition or anisotropy orientation [8-11].

The microstructural mechanisms that control the strain accommodation in gypsum have for long time interested the scientific world and are still not completely understood [12-14]. The coalescence of cracks in synthetic and natural gypsum samples have been successfully investigated by means of the visual analysis and comparison of photographic sequences [1519]. However, this methodology cannot be directly applied to more complex loading conditions, when the sample is inserted in a visual opaque structure for the application of a confining pressure.

A largely used methodology for the investigation of samples interested by triaxial loading conditions is the analysis of the microstructures on thin sections. Zucali et al. [20] proposed a description of the microstructural changes induced to gypsum rock under large strains, Brantut et al. [21] investigated the mechanisms involved in the strain of gypsum with microstructural analysis and acoustic emission, deepening the field of the transition between brittle and ductile regimes. Both concluded that the deformation mechanism of gypsum may involve the coexistence of plastic and brittle microstructures.

The present paper proposes an experimental investigation of gypsum response under uniaxial and triaxial compression. The mechanical data were associated to a multiscale analysis of the effects induced on the material by the compression. Digital Image Correlation (DIC) analysis and microstructural investigation techniques were adopted. The study aims to propose a description of the mechanisms involved in the strain accommodation and crack coalescence of natural gypsum and of their relation with the increase of confining pressure, with a specific focus on the influence of the rock texture and layering on the mechanical response.

In the paper, the rock mechanics sign convention is adopted, with compressive stress and strains considered as positive.

\section{MATERIAL AND METHODS}

he tested material is a gypsum rock facies deposed in the Monferrato area (NW Italy) during the Messinian Salinity Crisis, a period of anomalous paleo-oceanographic conditions that brought to the deposition of enormous volumes of gypsum, anhydrite and halite all over the Mediterranean basin. The gypsum rocks deposed during the Crisis have a large variability of facies, with big differences in terms of grain size, porosity and mineralogical composition. However, each facies may have a large distribution through the Mediterranean [22-24]. As instance, the branching selenite facies (object of the present experimental investigation) have been recognized and described in the same stratigraphic position in several areas of the Mediterranean (i.e. Spain, Cyprus, Central Italy). It consists of nodules and irregular lenses of white gypsum crystals (mean size 1-2 mm) surrounded by laminae of finer material, containing gypsum, calcite, dolomite, quartz, feldspar and clay minerals. Despite the availability of data about the stratigraphic features of this rock facies [23,25,26], a lack in mechanical data was recognized in the scientific literature.

In order to investigate the micromechanical processes involved in the deformation and failure of the rock, different techniques were applied. The failure coalescence in uniaxial stress conditions was investigated by means of DIC analysis. The uniaxial test was performed on a prismatic sample to facilitate the video acquisition and processing. The axial compression (displacement rate of $0.03 \mathrm{~mm} / \mathrm{min}$ ) was applied with a GDS Instruments Medium Pressure Triaxial Apparatus (MPTA) adapted to work without the oil cell, applying only the axial compression and leaving the sample visible. The evolution of axial stresses and axial strains during the test was calculated considering the initial area and axial length of the sample as reference. The in-continuous measurements of loads (from the load-cell) and axial displacements (from the piston movement) complete the set of data used to retrieve the axial stress-strain paths. The sample face was filmed throughout the test with a digital camera. The final video was then processed with Ncorr v.1.2.2 software [27], as described in [17]. For the present application, the elaboration was started at a strain of $0.8 \%$ (i.e. in correspondence of the onset point), to avoid the noise produced by the elastic deformation phase and focalize the analysis on the failure coalescence.

The DIC procedure is not suitable for the analysis of samples in triaxial stress conditions, because the presence of the oil cell inhibits the acquisition of photographic images during the test. For this reason, the analysis of the strain accommodation mechanisms under triaxial compression was performed by microstructural analysis at the end of the test. The tests were performed with the same GDS MPTA machine used for the uniaxial compression. An isotropic phase brought to the desired conditions of pressure in the oil cell (i.e. confining pressures of 4, 6, $8 \mathrm{MPa}$ ). The axial stress was then increased with a constant displacement rate of $0.03 \mathrm{~mm} / \mathrm{min}$. In addition to the measures of deviatoric stress and axial strain (analogous to the uniaxial test), the volumetric strain path was retrieved considering the changes of volume of the oil in the cell with 
respect to the initial volume of the sample. At the end of the test, samples were cut to prepare thin sections for the analysis with optical microscope and SEM (Scanner Electron Microscope).

The shape of the samples (prismatic or cylindrical - Fig. 1) depends, therefore, on the performed test and on the method used for the investigation of failure mechanisms. All the samples have height of $100 \mathrm{~mm}$ and diameter (or side) of $50 \mathrm{~mm}$. The upper and lower faces were polished and rectified in order to obtain flat and parallel surfaces.
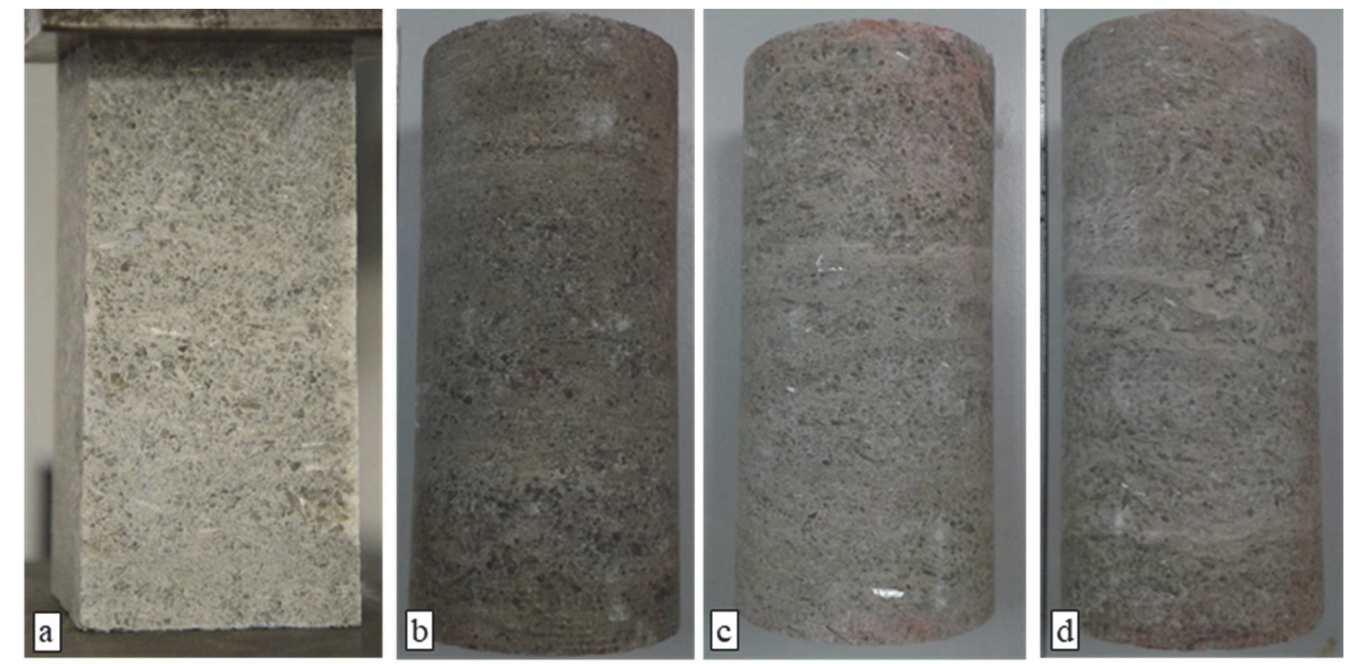

Figure 1: Samples for the uniaxial tests (a) and triaxial tests with confining pressure of $4 \mathrm{MPa}(\mathrm{b}), 6 \mathrm{MPa}$ a(c) and $8 \mathrm{MPa}$ (d).

\section{RESUlts}

$\mathrm{F}$

ig. 2 shows the stress-strain curves for the four tested samples. The curves are ordered following the increasing confining pressure, from $0 \mathrm{MPa}$ (i.e. Uniaxial Compression) to $8 \mathrm{MPa}$. Resulting peak stresses are reported in Tab. 1. The curves describe a clear change in behaviour: in uniaxial conditions, the material reaches a strength peak and is then characterized by a strain softening deformation. The post-peak strain softening curve consists of a series of stressdrops, followed by a short recovering phase, then interrupted by a new drop and so on.

With the introduction of a confinement, the strain to accommodate significantly increases: the strain softening is replaced by a long phase of stress stability that gives place to a slight strength decrease only around a strain of $5 \%$. When the confining pressure reaches $8 \mathrm{MPa}$, no strain-softening is observed for the entire duration of the test (i.e. axial strain higher than $6 \%$ ). The stress-drop behaviour is also observed in triaxial loading condition, particularly in the sample deformed at Pc $=6 \mathrm{MPa}$. The decrease of strain softening suggests a gradual disappearance of the macroscopic fragile cracks in the post-test samples. On this regard, the macroscopic features of the samples show a good agreement with the stress-strain curves. Fig. 3 shows the final images of the samples associated with a schematic representation of their shape and fracturing. With the increasing of confining pressure and the hardening of the material, we registered a transition from a structure characterized by a single, localized failure surface (Fig. 3a-b) to the presence of a more diffuse fracturing, with conjugate structures (Fig. 3c), to the total absence of visible fracturing (Fig. 3d). Both the localized failure surfaces of Fig. 3a-b and the diffuse fracturing in Fig. $3 \mathrm{c}$ are well evident on both the sides of the samples, while sample in Fig. $3 \mathrm{~d}$ does not show any macroscopic crack on any side of the sample surface. A constant angle with the main loading direction can be observed. In Fig. 3a, 3b and $3 \mathrm{c}$ an angle $\alpha$ with the horizontal surface of $60^{\circ}$ was measured. Considering a failure envelope estimated on the base of the results of triaxial tests (Fig. 4), the angle of cracking on the samples is coherent with the friction angle $\varphi$ of the material, following

$$
\alpha=\varphi / 2+\pi / 4
$$

The final shape of the samples is also influenced by the confining pressure: in the uniaxial test the shape is almost unchanged, while samples under triaxial loading show an increasing propensity to localize a volumetric strain in the central part (barrel shape). 


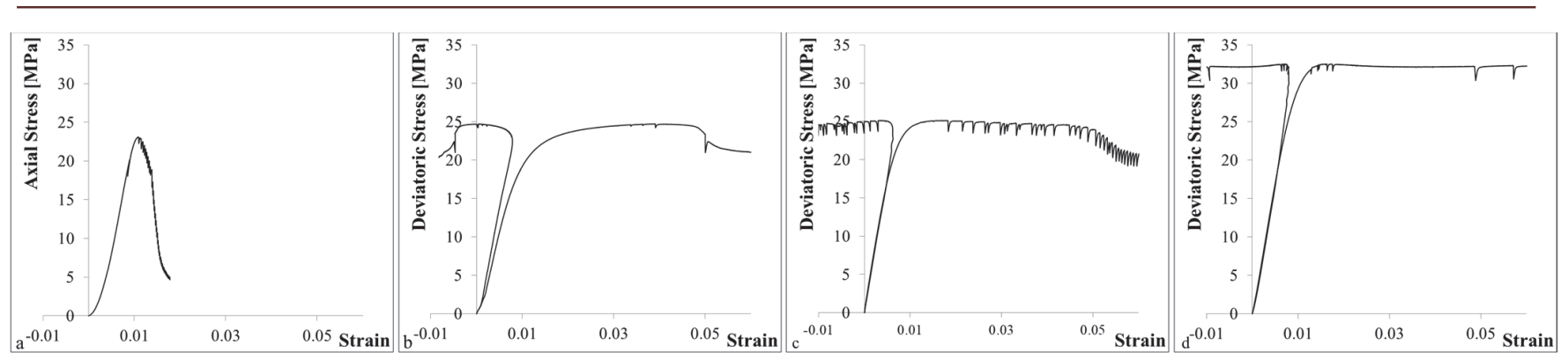

Figure 2: a. Axial strain curve of uniaxial test. b. Axial and volumetric strain of triaxial test with confining pressure of 4 MPa c. Axial and volumetric strain of triaxial test with confining pressure of $6 \mathrm{MPa}$. Axial and volumetric strain of triaxial test with confining pressure of $8 \mathrm{MPa}$

\begin{tabular}{ccc}
\hline Sample & Confining Pressure [MPa] & Peak Deviatoric Stress [MPa] \\
a & 0 & 23.10 \\
b & 4 & 24.72 \\
c & 6 & 25.13 \\
d & 8 & 32.54 \\
\hline
\end{tabular}

Table 1: Results of Peak stress for the uniaxial test (Sample a) and the three triaxial tests (Samples b-c-d)

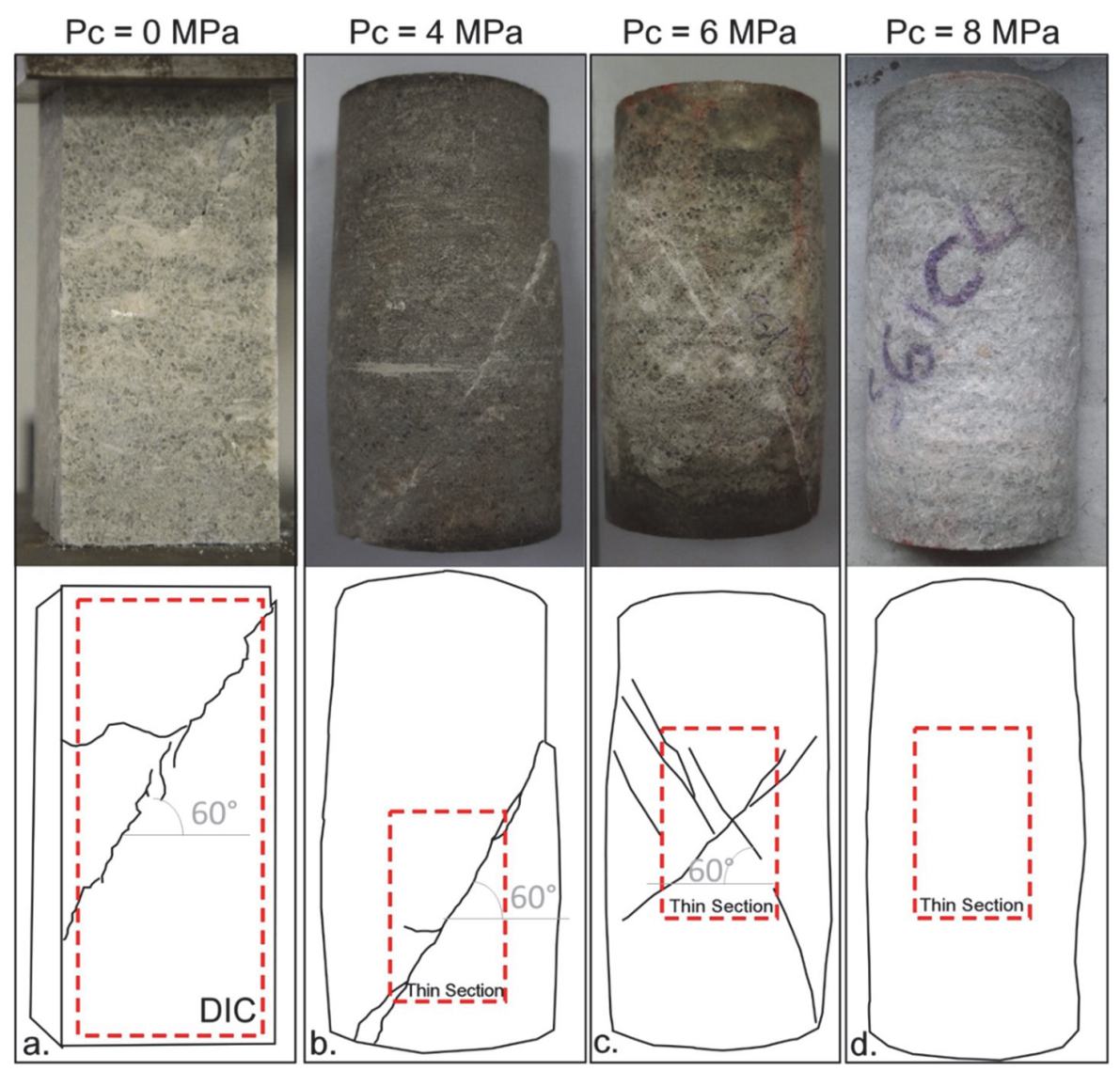

Figure 3: Photographic images and schemes of samples at the end of the uniaxial test (a) and of the triaxial tests with confining pressure of $4 \mathrm{MPa}(\mathrm{b}), 6 \mathrm{MPa}$ a(c) and $8 \mathrm{MPa}(\mathrm{d})$.

The clear localization of the failure surface in the sample under uniaxial compression is also observed in the results of DIC analysis (Fig. 5). The map of axial strains (Fig. 5b) describes the additional presence of a sub-horizontal crack that reproduces the shape and orientation of the layering in the rock. A similar evidence was recognized in the macroscopic observation of the sample (Fig. 3a), attesting a good reliability of the DIC results. The failure of weaker layers of the rock, even if manifested 
only in late phases of the test, is an important element in the strain accommodation (intended as the set of processes occurring in the rock during the application of an external load, allowing for the shortening of the sample).

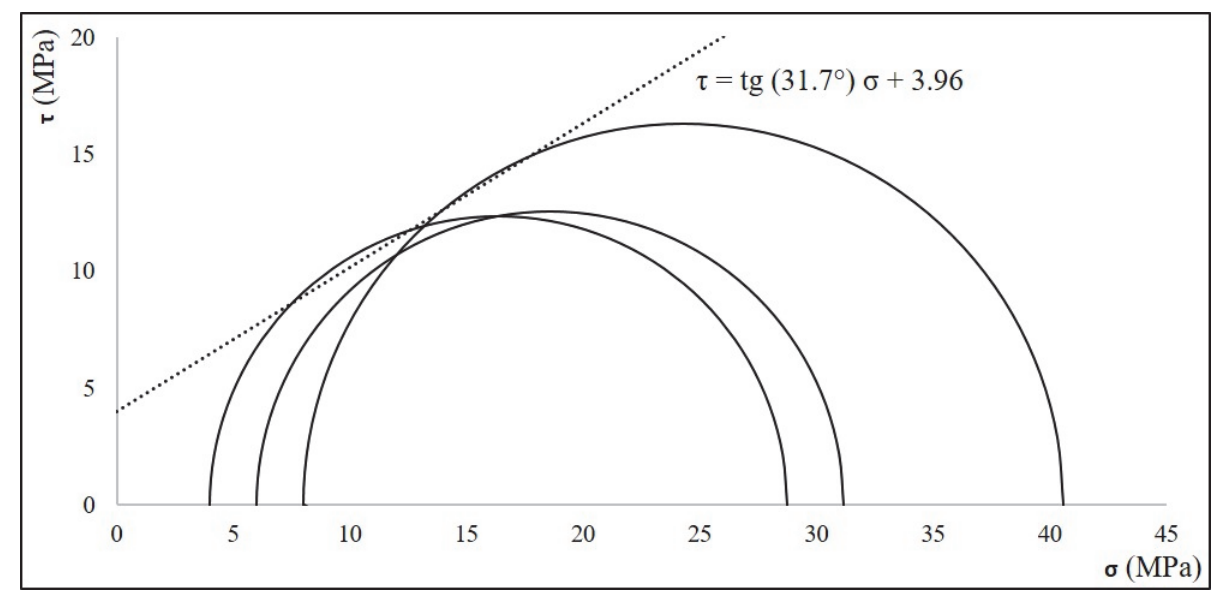

Figure 4: Mohr circles and failure envelope estimated on the base of the results of triaxial tests.
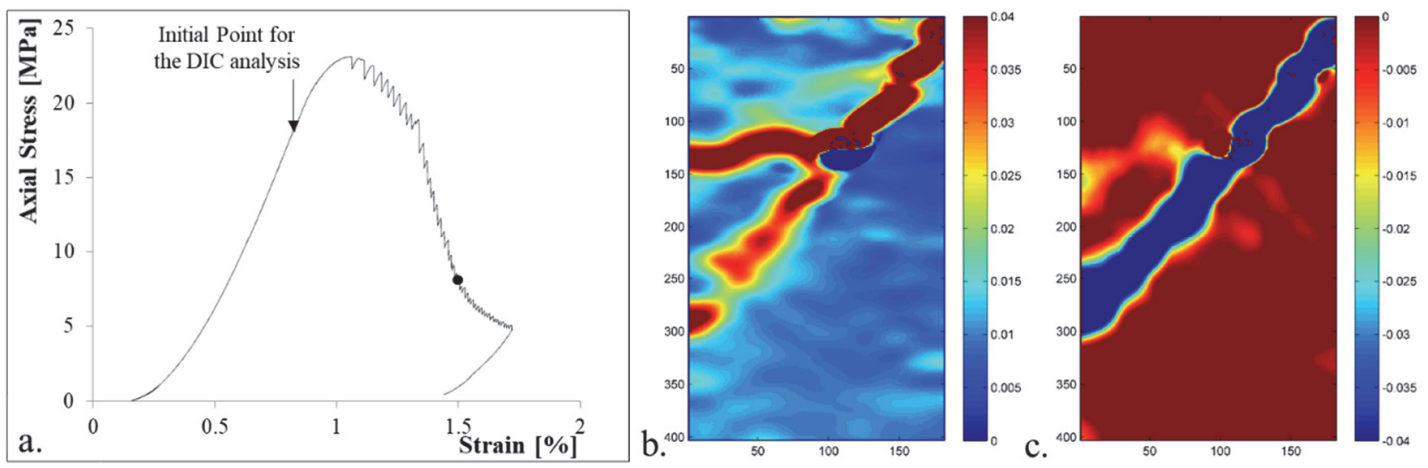

Figure 5: a. Stress-strain curve of the uniaxial test, with location of the initial point for the DIC analysis (black arrow) and of the strain maps in Figs. b and c (black point). b. Map of axial strains. c. Map of lateral strains.

As already noticed, several stress drops characterize the post-peak stress-strain behaviour in uniaxial conditions. Fig. 6 shows the maps of lateral strains obtained with DIC analysis in this part of the stress-strain curve. Each line of the Figure reports three images before and three images after the drop. The stress-strain graphs show the correspondent position of the drops. The image attests a step-propagation of the crack coalescence: in each line, a sudden advancement of the failure is registered in correspondence of the stress drop. The three images before the drop and after the drop are almost identical and only at the moment of the drop itself the failure coalescence has a new step.

This kind of behaviour is consistent for all the duration of the strain softening, suggesting a mechanism of steppingcoalescence of the failure surface.

Fig. $6 \mathrm{~d}$ refers to the biggest stress drop in the curve. It marks a change in the curve slope, starting a phase of faster strength degradation. This crucial point of the stress-strain path corresponds to the complete development of the failure surface that, in the last step in Fig. 6d, connects the two sides of the sample.

The introduction of a confining pressure does not inhibit the possibility of a failure coalescence. Up to a confining pressure of $6 \mathrm{MPa}$, a clear failure surface is recognizable in the samples, both at the macroscale (Fig. 3b-c) and at the microscale (Fig. 7 and 8). At a microscopic insight, these failure surfaces appear to be accompanied by a larger deformation area, consisting of crashed grains, as highlighted in the micrograph in Fig. 7c. The phenomenon of grain crashing, however, is not only localized along the failure surface, but also interests other portions of the rock. As instance, Fig. 7a shows an intense crashing phenomenon on a gypsum crystal, which left edge gradually turns into fine-grained crashed gypsum. Similar evidences characterize several portions of the sample and seem to be particularly concentrated in the finer layers of the rock, in accordance with the sub-horizontal crack observed in the uniaxial sample. 
Beside the presence of a brittle deformation (explicated in form of failure surface), the sample deformed at Pc $=4 \mathrm{MPa}$ shows some evidences of a plastic intra-crystalline deformation (e.g. Fig. 7b).

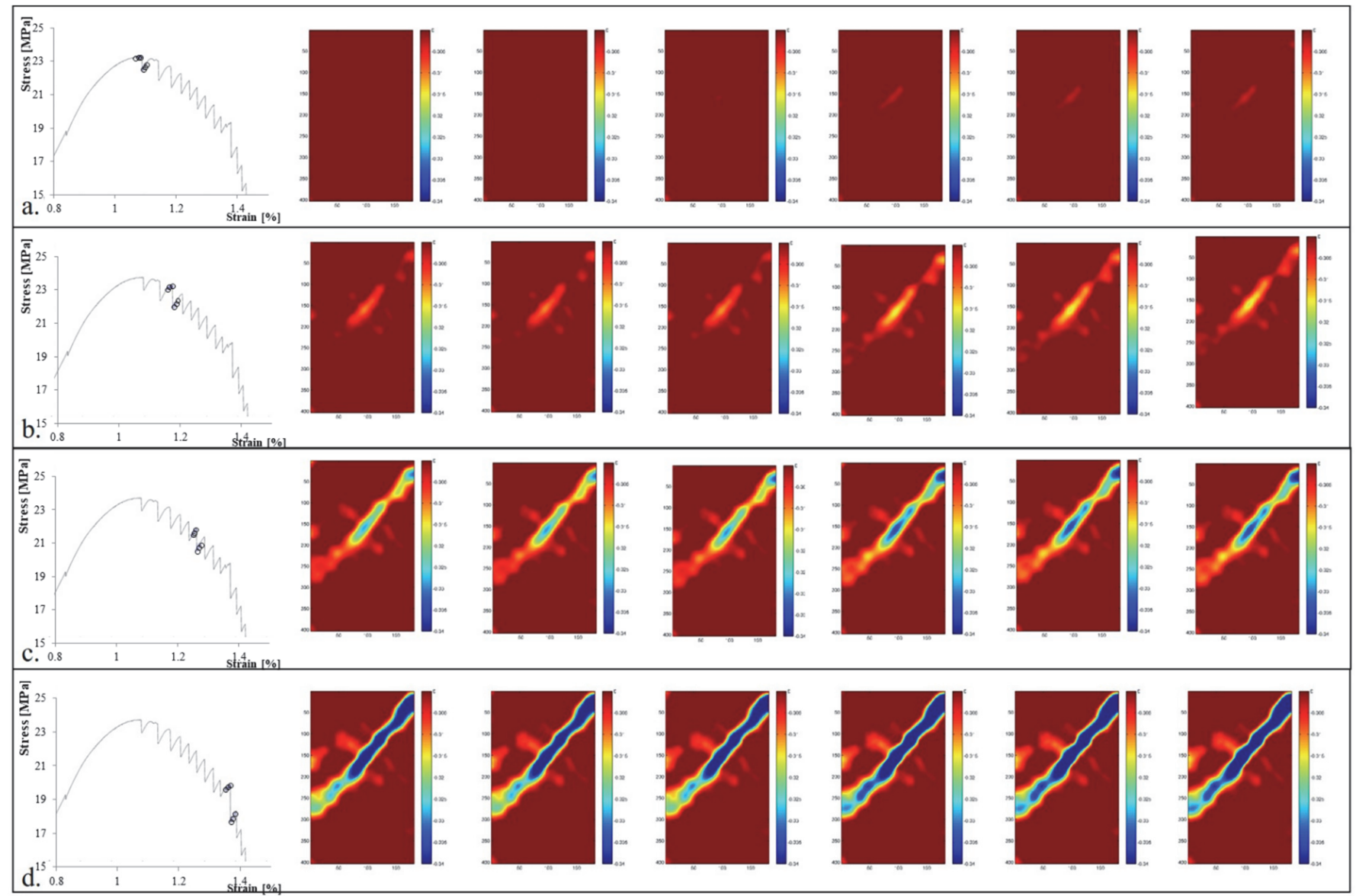

Figure 6: Stepping failure coalescence registered with DIC analysis. Each line reports six maps of lateral strains. The position of the maps is shown by the blue dots in the stress-strain graphs a. First stress drop, with the first evidence of a crack. b. Accretion of the failure surface. c. Coalescence of two failure edges in the upper part of the sample. d. Complete coalescence of the failure on the entire surface of the sample.
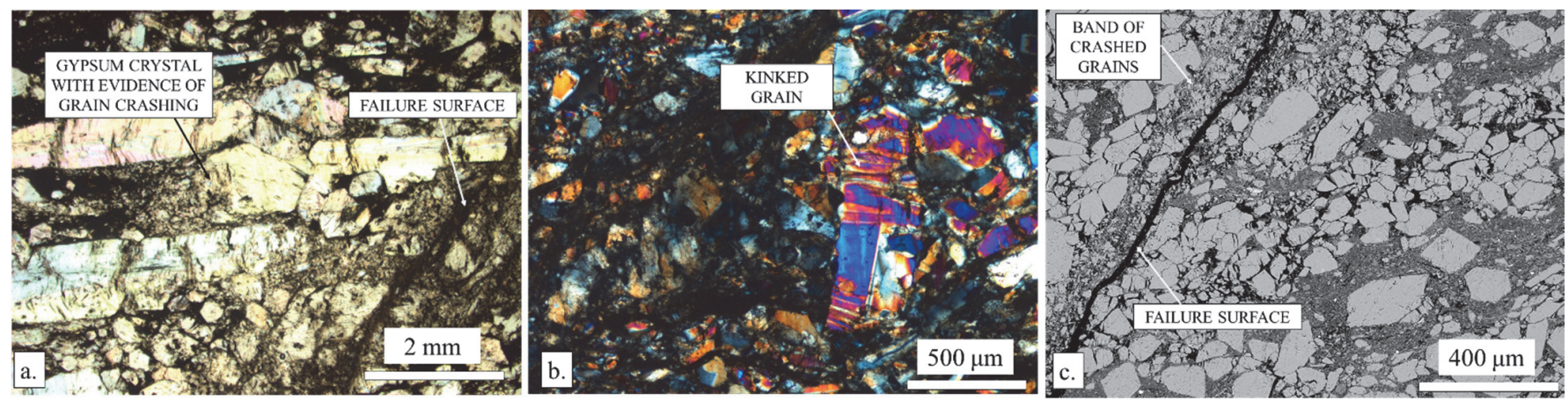

Figure 7: Micrographs of gypsum sample deformed with a confining pressure of $4 \mathrm{MPa}$. a. Failure surface and evidences of grain crashing at optical microscope in reflected light. b. Kinked grain, in optical microscope with crossed nicols. c. Failure surface, observed at the SEM.

At Pc $=6 \mathrm{MPa}$, the brittle regime is still the principal mode of strain accommodation, with the presence of a well-defined failure surface (Fig. 8a). However, the thin section reveals the additional presence of a conjugate structure. As can be seen 
in Fig. 8b, the central part of this structure consists of a diffuse fracturing that creates a zone of crashed grains. This central band is accompanied by a larger area of fracturing that helps in the accommodation of the relative displacement of the upper and the lower portions of material.

In this sample, the presence of intra-crystalline plastic structures became more evident (e.g. Fig. 8c). The crystals appear to be deformed for the effect of a kink folding, i.e. a folding mechanism with straight limbs and pointed hinges that is usually associated to materials with a fine, regular layering. In the present framework, the regular layering corresponds to the mineral cleavage along the (010) crystallographic direction. This cleavage reproduces the sandwiched crystallographic structure of gypsum, with an alternation of sheets of $\mathrm{Ca} 2+$ and (SO4)2- ions and double-sheets of water molecules. The weakness of the water-water chemical bonds favours the formation of the mineral cleavage.

This kind of plastic mechanism seems to be activated by the lateral confinement, becoming more evident and pervasive with the increase of confining pressure.

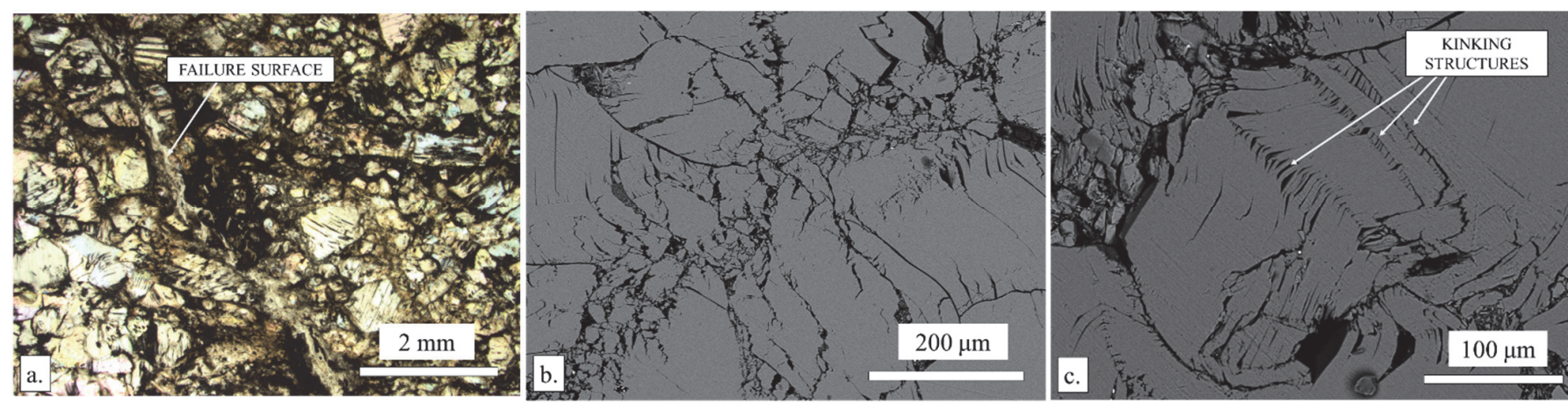

Figure 8: Micrographs of gypsum sample deformed with a confining pressure of $6 \mathrm{MPa}$. a. Failure surface, observed at optical microscope in reflected light. b. Shear band oriented as a conjugate, observed at the SEM c. Kinked grain at the SEM

In the sample deformed at $\mathrm{Pc}=8 \mathrm{MPa}$, indeed, the presence of kinked grains becomes the principal effect of strain accommodation, involving all the biggest gypsum crystals (Fig. 9).

The presence of kinked grains can be easily recognized with the optical microscope at crossed nicols, since the change in orientation of the crystal implies a change in the interference colour (e.g. Fig. 9b). The kinking structures are preferentially concentred on gypsum crystals oriented in vertical direction (i.e. with the cleavage planes parallel to the principal stress $\sigma 1$ ). This confirms the connection between this kind of structure and the mineral cleavage.

As suggested by [21], who observed similar structures in triaxially loaded samples of Volterra gypsum, the grain kinking is a hardening mechanism: after a certain amount of strain, the energy needed to further deform a specific grain becomes larger than the energy needed to start to deform a new grain. This is coherent with the transition of behaviour from strain softening to strain hardening observed in the mechanical tests.
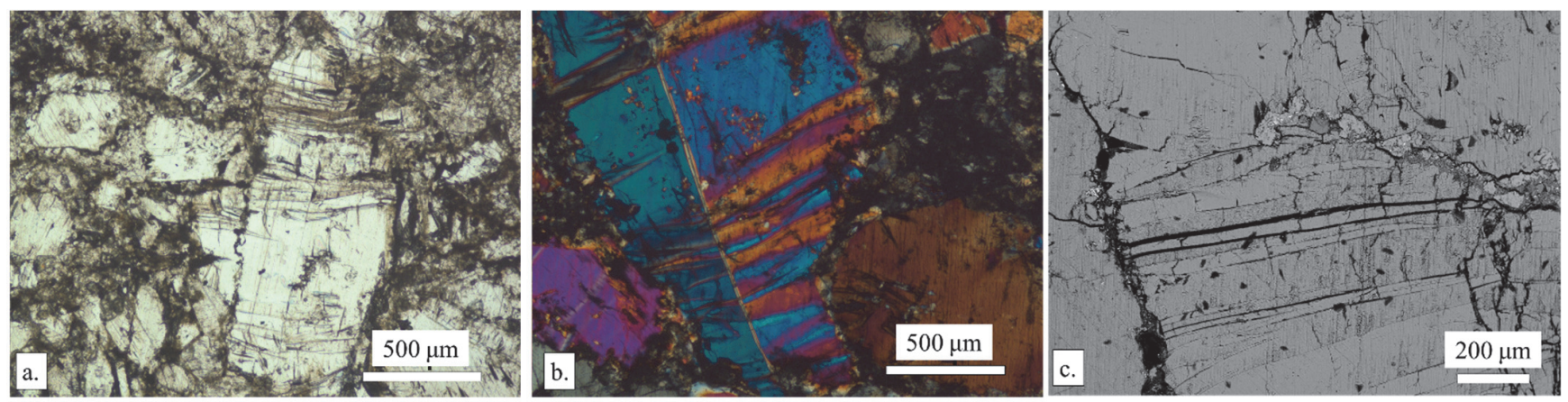

Figure 9: Micrographs of gypsum sample deformed with a confining pressure of $8 \mathrm{MPa}$. a. Kinked grain, in optical microscope with reflected light. b. Kinked grain, in optical microscope with crossed nicols. c. Gypsum crystal with kinking structure and sharp cracks along the kink borders, observed at the SEM..

As a confirmation of this idea, Fig. 9c proposes the SEM micrograph of a kinked grain with sharp cracks along the boundaries of the kink bands. This evidence suggests that each gypsum crystal can accommodate with plastic kinking only 
a finite amount of strain. The further increase of deformation on that specific grain brings to failure. If the kinking process exploits the weak chemical bond among gypsum water molecules, the failure of the crystal necessarily implies the involvement of the salt structure (ionic bond between $\mathrm{Ca}^{2+}$ and $\left(\mathrm{SO}_{4}\right)^{2-}$ ions), requiring an higher level of energy.

As already described in Fig. 3, the macroscopic observation suggests, for this sample, the absence of a defined failure surface. This absence of a clear coalesced failure surface is confirmed by the microstructural observations, that show, on the other hand, the increase kinking structures. The sum of these two elements suggests that the energy that would be needed for coalesce a failure surface is, in these test conditions, dissipated in the development of plastic structures (i.e. kink folding).

\section{DisCUSSIONS AND CONCLUSIONS}

$\mathrm{W}$ e proposed an experimental investigation aimed to the observation and description of the micromechanical processes involved in the failure coalescence and strain accommodation of gypsum rock.

The described data include uniaxial and triaxial mechanical tests. The uniaxial test configuration allows for the visual access to the sample during the test. Hence, sample strain and crack coalescence were investigated by means of DIC procedure, with the comparison of sequential photographic images. In the triaxial test configuration, the oil cell hides the sample during the test, preventing the acquisition of photographic images. Therefore, triaxial samples were investigated by thin section analysis with optical microscope and SEM.

DIC results highlighted the presence of a stepping coalescence of the failure surface that well relates with the record of stress drops in the stress-strain curves, attesting the existence of a step-wise unstable crack growth.

A similar stress-drop unstable post-peak behaviour was registered also in presence of a lateral confinement. Considering the stability of failure angle (i.e. about $60^{\circ}$ despite the increase in confining pressure) a substantial similarity of crack mechanism can be imagined.

However, a large increase in axial strain was registered in the mechanical tests with the introduction of a confining pressure. This can be explained considering the appearance of an intra-crystalline plastic strain mechanisms (i.e. the "kinking" of the grains). The effect of the lateral confinement activates these plastic mechanisms, dissipating energy that would otherwise be used to coalesce new cracks. With the increase of confining pressure, the plastic mechanisms became energetically more advantageous, while the possibility to open and coalesce tensional cracks is disadvantaged.

\section{ACKNOWLEDGEMENTS}

7 he Authors desire to acknowledge the Geotechnical Laboratory of the Department of Structural, Geotechnical and Building Engineering of the Polytechnic of Turin, where the described mechanical tests were performed.

\section{REFERENCES}

[1] Van Driessche, A.E.S., Stawski, T.M. and Kellermeier, M. (2019). Calcium sulfate precipitation pathways in natural and engineering environments, Chem. Geol. 570. DOI: 10.1016/j.chemgeo.2019.119274.

[2] Auvray, C., Homand, F. and Sorgi, C. (2004). The aging of gypsum in underground mines, Eng. Geol. 74 (3-4), pp. 183-196. DOI: 10.1016/j.enggeo.2004.03.008.

[3] Castellanza, R., Nova and R., Orlandi, G. (2010). Evaluation and remediation of an abandoned gypsum mine, J. Geotech. Geoenvironmental Eng. 136 (4), pp. 629-639. DOI: 10.1061/(ASCE)GT.1943-5606.0000249.

[4] Castellanza, R., Gerolymatou and E., Nova, R. (2008). An Attempt to Predict the Failure Time of Abandoned Mine Pillars, Rock Mech. Rock Eng. 41 (3), pp. 377-401. DOI: 10.1007/s00603-007-0142-y.

[5] Caselle, C., Bonetto, S., Comina, C. and Stocco S. (2020). GPR surveys for the prevention of karst risk in underground gypsum quarries, Tunn. Undergr. Space Technol. 95. DOI: 10.1016/j.tust.2019.103137.

[6] Caselle, C., Bonetto, S. and Comina, C. (2019). Comparison of laboratory and field electrical resistivity measurements of a gypsum rock for mining prospection applications, Int. J. Min. Sci. Technol. 29(6), pp. 841-849.

DOI: 10.1016/j.ijmst.2019.09.002.

[7] Liang, W., Yang, X., Gao, H., Zhang, C., Zhao, Y. and Dusseault, M.B. (2012). Experimental study of mechanical properties of gypsum soaked in brine, Int. J. Rock Mech. Min. Sci. 53, pp. 142-150. DOI: 10.1016/j.ijrmms.2012.05.015. 
[8] Caselle, C., Bonetto, S., Vagnon, F. and Costanzo, D. (2019). Dependence of macro mechanical behaviour of gypsum on micro-scale grain-size distribution, Géotechnique Lett. 9(4), pp.290-298. DOI: 10.1680/jgele.18.00206.

[9] Caselle, C., Penone, A. and Bonetto, S. (2018). Preliminary mechanical characterisation of gypsum rock using UCS and Point Load Test correlation, Geoing. Ambient. E Mineraria. 153(1), pp. 60-67.

[10] Caselle, C., Bonetto, S., Colombero, C. and Comina, C. (2019). Mechanical properties of microcrystalline branching selenite gypsum samples and influence of constituting factors, J. Rock Mech. Geotech. Eng. 11(2), pp. $228-241$. DOI: $10.1016 /$ j.jrmge.2018.09.003.

[11] Caselle, C., Bonetto, S., Vagnon, F. and Costanzo, D. (2018). Preliminary results of gypsum mechanical characterization, in: Geomech. Geodyn. Rock Masses, pp. 1123-1128.

[12] Craker, W.E. and Schiller, K.K. (1962). Plastic deformation of gypsum, Nature. 193, pp. 672-673. DOI: $10.1038 / 193672 \mathrm{a} 0$.

[13] de Meer, S. and Spiers, C.J. (1997). Uniaxial compaction creep of wet gypsum aggregates, J. Geophys. Res. Solid Earth. 102 (B1), pp. 875-891. DOI: 10.1029/96JB02481.

[14] Hoxha, D., Homand, F. and Auvray, C. (2006). Deformation of natural gypsum rock: Mechanisms and questions, Eng. Geol. 86(1), pp. 1-17. DOI: 10.1016/j.enggeo.2006.04.002.

[15] Bobet, A. and Einstein, H.H. (1998). Fracture coalescence in rock-type materials under uniaxial and biaxial compression, Int. J. Rock Mech. Min. Sci. 35(7), pp. 863-888. DOI: 10.1016/S0148-9062(98)00005-9.

[16] Caselle, C., Umili, G., Bonetto, S., Costanzo, D. and Ferrero A.M. (2020). Evolution of Local Strains Under Uniaxial Compression in an Anisotropic Gypsum Sample, in: Geotechnical Research for Land Protection and Development, Springer International Publishing, pp. 454-461.

[17] Caselle, C., Umili, G., Bonetto, S., Ferrero, A.M. (2019). Application of DIC analysis method to the study of failure initiation in gypsum rocks, Géotechnique Lett. 9(1) pp. 35-45. DOI: 10.1680/jgele.18.00156.

[18] Sagong, M. and Bobet, A. (2002). Coalescence of multiple flaws in a rock-model material in uniaxial compression, Int. J. Rock Mech. Min. Sci. 39(2) pp. 229-241. DOI: 10.1016/S1365-1609(02)00027-8.

[19] Wong, L.N.Y. and Einstein, H.H. (2009) Crack coalescence in molded gypsum and Carrara marble: Part 1. Macroscopic observations and interpretation, Rock Mech. Rock Eng. 42(3) pp. 475-511. DOI: 10.1007/s00603-008-0002-4.

[20] Zucali, M., Barberini, V., Chateigner, D., Ouladdiaf, B. and Lutterotti, L. (2010). Brittle plus plastic deformation of gypsum aggregates experimentally deformed in torsion to high strains: Quantitative microstructural and texture analysis from optical and diffraction data, Geol. Soc. Lond. Spec. Publ. 332, pp. 79-98. DOI: 10.1144/SP332.6.

[21] Brantut, N., Schubnel, A. and Guéguen, Y. (2011). Damage and rupture dynamics at the brittle-ductile transition: The case of gypsum, J. Geophys. Res. Solid Earth. 116(B1). DOI: 10.1029/2010JB007675.

[22] CIESM. (2008). The Messinian Salinity Crisis from mega-deposits to microbiology - A consensus report, in: $\mathrm{N}^{\circ} 33$ CIESM Workshop Monogr. CIESM Publ. Monaco.

[23] Lugli, S., Manzi, V., Roveri, M. and Schreiber, C.B. (2010). The Primary Lower Gypsum in the Mediterranean: A new facies interpretation for the first stage of the Messinian salinity crisis, Palaeogeogr. Palaeoclimatol. Palaeoecol. 297(1), pp. 83-99. DOI: 10.1016/j.palaeo.2010.07.017.

[24] Roveri, M., Flecker, R., Krijgsman, W., Lofi, J., Lugli, S., Manzi, V., Sierro, F.J., Bertini, A., Camerlenghi, A., De Lange, G., Govers, R., Hilgen, F.J., Hübscher, C., Meijer, P.T. and Stoica, M. (2014). The Messinian Salinity Crisis: Past and future of a great challenge for marine sciences, Mar. Geol. 352, pp. 25-58. DOI: 10.1016/j.margeo.2014.02.002.

[25] Dela Pierre, F., Bernardi, E., Cavagna, S., Clari, P., Gennari, R., Irace, A., Lozar, F., Lugli, S., Manzi, V., Natalicchio, M., Roveri, M. and Violanti, D. (2011). The record of the Messinian salinity crisis in the Tertiary Piedmont Basin (NW Italy): The Alba section revisited, Palaeogeogr. Palaeoclimatol. Palaeoecol. 310(3-4), pp. 238-255.

DOI: $10.1016 /$ j.palaeo.2011.07.017.

[26] Irace, A., Dela Pierre, F. and Clari P. (2005). «Normal» and «chaotic» deposits in the Messinian Gessoso-solfifera Fm. at the north-eastern border of the Langhe domain (Tertiary Piedmont basin), Boll. Della Soc. Geol. Ital. 4, pp. 77-85.

[27] Blaber, J., Adair, B. and Antoniou, A. (2015). Ncorr: Open-Source 2D Digital Image Correlation Matlab Software, Exp. Mech. 55(6), pp. 1105-1122. DOI: 10.1007/s11340-015-0009-1. 